\title{
Establishment of Callus Induction and Cell Suspension Cultures of Dendrathema Indicum var. Aromaticum a Scented Chrysanthemum
}

\author{
Liyan Jin ${ }^{1, *}$, Yang Yang ${ }^{1, *}$, Wenjie Gao ${ }^{1}$, Mingxue Gong ${ }^{1}$, Jijia Wang ${ }^{1}$, Neil O. Anderson ${ }^{2} \&$ Miao He ${ }^{1,2}$ \\ ${ }^{1}$ Department of Landscape Architecture of Northeast Forestry University, 26 Hexing Road, Harbin, Heilongjiang \\ 150040, China \\ ${ }^{2}$ Department of Horticulture, University of Minnesota, Saint Paul, MN 55108, USA \\ *Both authors contributed equally to this work. \\ Correspondence: Miao He, Department of Landscape Architecture of Northeast Forestry University, 26 Hexing \\ Road, Harbin, Heilongjiang 150040, China.Tel: 1-361-364-9547. E-mail: hemiao_xu@126.com
}

Received: February 9, 2017

Accepted: March 18, 2017 Online Published: April 24, 2017

doi:10.5539/jps.v6n2p38

URL: https://doi.org/10.5539/jps.v6n2p38

\begin{abstract}
Dendranthema indicum var. aromaticum is an important aroma plant in genus Dendrathema, and the establishment of callus cultures and cell suspension cultures is the basement of further protoplast fusion studies, which make it possible to breed new fragrant chrysanthemum. In this study, the effects of different plant growth regulating substances in different concentrations on callus induction were investigated with stem segments, leaves, petioles as explants. The results showed that the optimal explants were lower stem segments according to the percentage of callus formation, callus hardness, growth potential and shoot differentiation. The optimal induction mediums were MS supplemented with $1.0 \mathrm{mg} \cdot 1^{-1} 2.4 \mathrm{D}$ and $0.2 \mathrm{mg} \cdot 1^{-1} 6-\mathrm{BA}$. The cell suspension culture system was established by using the subculture calli. The results showed that the suitable inoculum size was $2 \mathrm{~g}$ and the suitable cell suspension culture medium was MS supplemented with $0.2 \mathrm{mg} \cdot \mathrm{l}^{-1}$ 6-BA and 0.5 $\mathrm{mg} \cdot \mathrm{l}^{-1} 2,4-\mathrm{D}$. The time course of cell growth showed that the greatest cell fresh weight appeared on day 14 and the highest cell viability on day 3 .
\end{abstract}

Keywords: scented Chrysanthemum, in vitro, explants, callus formation, cell culture

\section{Introduction}

\subsection{Introduce the Problem}

Chrysanthemum (Dendrathemaxgrandiflora), one of the famous traditional flowers in China, is widely cultivated in the world. Flowers of Chrysanthemum with brightly colored flowers and varied flower types are not fragrant or with a slightly scent. Thus, the improvement of Chrysanthemum's aroma is an important topic in chrysanthemum breeding.

Dendranthema indicum var. aromaticum is an herbaceous perennial plant characterized by special scent, which is the important aroma resource in genus Dendrathema and found in Shennongjia, Hu Bei province, P. R. China (Liu, Jia, \& Yang, 1983). Previous research has proved that Dendranthema indicum var. aromaticum was diploid $(2 \mathrm{n}=2 \mathrm{x}=18)$ and Dendrathema $\times$ grandiflora was polypoild $(2 \mathrm{n}=6 \mathrm{x}=54)(\mathrm{Zhu}, \mathrm{Liu}, \& \mathrm{Dai}, 2011)$. As we know that it is difficult to cross breed if one species is diploid while the other is a higher ploidy level. In order to breed scented chrysanthemum, somatic hybridization will be applied. Somatic hybridization is to hybrid plants through the fusion of somatic protoplasts of two different plant species/varieties, with which some interspecific hybrids have been obtained in family Compositae, for example the hybrids between Helianthus annuas and H. giganteus (Henn, Wingender, \& Schnabl, 1998; Krasnyanski, \& Menczel, 1995), Tanacetum vulgare and T. cinerariifolium (Keskitalo, Angers, Earle, \& Pehu,1999), Dendrathema $\times$ grandiflorum and Artemsia sieversiana(Lee, Paek, \& Hwang, 1995),ect.

The objective of this project was to establish callus cultures and cell suspension cultures of $D$. indicum var. aromaticum for further protoplast fusion studies, which make it possible to breed new fragrant chrysanthemum. 


\section{Materials and Methods}

\subsection{Plant Material and Callus Induction}

Seedlings of D. indicum var. aromaticum were obtained in 2008 from Shennongjia in the Hu Bei province, P. R. China and were maintained in the garden nursery, College of Landscape Architecture and Horticulture, Northeast Forestry University, Harbin, P. R. China. Shoots were surface sterilized first by washing under running tap water and laundry bleach for $10 \mathrm{~min}$, then disinfected in $2 \%$ or $5 \%$ sodium hypochlorite for 10 min and rinsed with sterile distilled water 6-8 times. Surface sterilized shoots were trimmed, prior to inoculation on the basal medium under sterile conditions. The subcultures were done at regular intervals incubated at $25 \pm 2^{\circ} \mathrm{C}$ with a $16-\mathrm{h}$ photoperiod and illumination of 2000 lx. Basal nutrient medium contained MS(Murashige \& Skoog,1962) salts and vitamins and sucrose $\left(30 \mathrm{~g} \cdot \mathrm{1}^{-1}\right)$.Nutrient medium $\mathrm{pH}$ was adjusted to 5.8 prior to addition of $8 \mathrm{~g} \cdot \mathrm{l}^{-1}$ Agar and the autoclaved $121^{\circ} \mathrm{C}$ for $20 \mathrm{~min}$.Fresh and healthy leaves $(2 \times 2 \mathrm{~mm}$ from the central plate),stem segments $(4 \mathrm{~mm}$ in length) and petioles were obtained from in vitro grown plants, then transferred on MS basal medium supplemented with different concentrations of 2,4-D $\left(0.0,0.5,1.0,1.5,2.0,2.5,3.0 \mathrm{mg} \cdot 1^{-1}\right), \mathrm{BA}\left(0.2 \mathrm{mg} \cdot \mathrm{1}^{-1}\right)$, sucrose $\left(30 \mathrm{~g} \cdot 1^{-1}\right)$ and agar $\left(8 \mathrm{~g} \cdot 1^{-1}\right)$. The $\mathrm{pH}$ of medium was adjusted to $5.8 \pm 0.1$.Each treatment combination consisted of three replications and maintained in the presence or absence of light.

\subsection{Cell Suspension Cultures and Cell Growth Determination}

Suspension cultures were established from friable calli. 1-4g fresh weight friable calli was transferred to $100 \mathrm{ml}$ Erlenmeyer flasks containing $50 \mathrm{ml}$ MS basal medium with BA $0.2 \mathrm{mg} \cdot 1^{-1}, 2,4-\mathrm{D} 0.5 \mathrm{mg} \cdot 1^{-1}, 30 \mathrm{~g} \cdot 1^{-1}$ sugar in order to optimize the suitable inoculum size. The research of effect of exogenous plant growth regulators on cell suspension cultures were carried out by using $2 \mathrm{~g}$ fresh weight friable calli, the best inoculum size, with different concentrations of 2,4-D,6-BA and NAA, which was designed by orthogonal design L9 (3 $3^{3}$ ).All the cell suspension cultures were placed on a rotary shaker with a speed of $90 \mathrm{rpm}$ at $25 \pm 2^{\circ} \mathrm{C}$ under a 16-h photoperiod and illumination of 1000 lx. The FWt was measured after 18 days of culture. Five flasks were used per treatment and each experiment was repeated third. Anovas and Duncan comparison tests for each evaluated factor were carried out using the SPSS 12.0 software.

\section{Results and Discussion}

\subsection{Effect of 2, 4-D and the Types of Explants on Callus Induction}

Different types of explants were placed on MS basal medium supplemented with different concentrations of 2,4-D and $0.2 \mathrm{mg} \cdot 1^{-1} \mathrm{BA}$ for 60 days of cultivation. The percentage of callus formation, growth potential, callus hardness and shoots per callus were evaluated according to the method of Fadi Chen (Chen, Jiang, \& Guo, 2003).

Some related research indicated that 2, 4-D played a more important role in callus formation from leaf and stem explants compared to BA (Satyavani, Ramanathan, \& Gurudeeban, 2011).But in this experiment, Calli were successfully generated in all treatments regardless of 2, 4-D concentration and different types of explants (Table 1).These results showed that leaf and stem explants were suitable for callus induction. Similar results were reported in callus induction of Corydalis saxicola and Orthosiphon stamineus, in which it were described that callus could be induced successfully from leaf, petiole, stem (Cheng, Yu, Hu, Chen, \& Sun, 2006).

The callus hardness was classified into level 1 to level 5 according to the visual observation. The higher hardness level showed the callus was more hardness, which was bad to cell suspension culture. The callus potential growth was also classified into level 1 to level 4 according to the growth from slow to fast. The percentage of callus formation was the highest with the leaf as exlants (Table 1), but the callus was more hardness and the potential growth was lower. As for further cell suspensions, the friable calli were better than the compact calli. Thus we thought that lower stem segments were the best explants because the induced calli hardness was smaller and the growth potential was the biggest although the percentage of callus formation was not the highest. And the optimum medium was MS containing $0.2 \mathrm{mg} \cdot 1^{-1} 6-\mathrm{BA}$ and $1.0 \mathrm{mg} \cdot 1^{-1} 2,4-\mathrm{D}$.

\subsection{Effects of Inoculum Size on Cell Suspension Cultures}

Suspension cultures were initiated by transferring 1-4 g fresh friable calli into $50 \mathrm{ml}$ MS medium in $100 \mathrm{ml}$ flasks. The inoculum size had a positive effect on biomass. Cell fresh weight reached the lowest value of $1.71 \mathrm{~g}$ at the inoculum size of $1 \mathrm{~g}$, and increased to the highest value of $5.88 \mathrm{~g}$ at $4 \mathrm{~g}$. But the highest proliferation ratio and the best cell growth status were observed at the inoculum size of $2 \mathrm{~g}$ (88.5) (Table 2), and its cell cluster was small round and well dispersed, cell suspension liquid was clear. 


\subsection{Effects of Exogenous Plant Growth Regulators on Cell Suspension Cultures}

The effect of these plant growth regulators on cell suspension culture was presented in Table 3 . There existed significant differences among all the treatments which were designed by orthogonal design L9 $\left(3^{3}\right)(a=0.05)$.In case of Treatment 4 and 7 the cell fresh weights (Fwt) were significantly higher than other treatments, and cell suspension liquids were clear the cell cluster was small and high dispersion. Therefore, the most suitable cell suspension culture medium for cell growth in $D$. indicum var. aromaticum was MS+0.2 $\mathrm{mg} \cdot 1^{-1} 6-\mathrm{BA}+0.5 \mathrm{mg} \cdot \mathrm{l}^{-1} 2$, 4-D.

\subsection{Time Course of Cell Growth}

The time course of cell growth has been studied by growing suspension cells in $100 \mathrm{ml}$ flasks, containing $40 \mathrm{ml}$ liquid MS medium with $0.2 \mathrm{mg} \cdot \mathrm{l}^{-1} 6-\mathrm{BA}, 0.5 \mathrm{mg} \cdot 1^{-1}$ 2,4-D and $30 \mathrm{~g} \cdot \mathrm{l}^{-1}$ sugar. As shown in Fig. 1, cell growth was slow during initial $6 \mathrm{~d}$ of cultivation. From day 6, biomass accumulated rapidly and reached the greatest value on day 14. Then a slow decrease of biomass was observed in the later stage of cultivation. These results showed that some cells which couldn't adapt to the change from solid to liquid medium and gradually went to death. After that, biomass increased rapidly and reached the highest value. Similar results were reported in Cleistocalyx operculatus (Zhou, Wang, \& Xiao, 2007), Dendrathema grandiflora (Jiang, 2002), Morus alba (Li Yong et al., 2007) .Cell viability was measured by TTC method (Steponkus \& Lanphear, 1967) using a Unic spectrophotometer, model UV-2102C, at $485 \mathrm{~nm}$ wavelength. The bigger OD value indicates the greater cell viability. The TTC test results showed cell viability increased in the initial $3 \mathrm{~d}$ followed by a gradual decrease. The growth patterns of cultures showed that cell viability was lower in its rapid growth, and higher in its slow growth stage, which was the same with Xanthoceras sorbifolia (Liu,2009)and Taxus cuspidata(Liu,2002).

In conclusion, the friable callus of $D$. indicum var. aromaticum could be efficiently introduced with lower stem segments as explants on MS medium supplemented with $1.0 \mathrm{mg} \cdot 1^{-1} 2.4 \mathrm{D}$ and $0.2 \mathrm{mg} \cdot 1^{-1} 6$-BA. $2 \mathrm{~g}$ fresh weight friable calli were the best inoculum size. The most suitable cell suspension culture medium was MS $+0.2 \mathrm{mg} \cdot 1^{-1}$ $6-\mathrm{BA}+0.5 \mathrm{mg} \cdot \mathrm{l}^{-1} 2,4-\mathrm{D}$. The growth patterns of cell cultures showed S-curve and the greatest cell fresh weight appeared on day 14 , the highest cell viability on day 3 . 
Table 1. Effect of 2,4-D and different types of explants on the callus induction

\begin{tabular}{|c|c|c|c|c|c|c|}
\hline $\begin{array}{l}\text { Treat-ment } \\
\text { code }\end{array}$ & $2,4-\mathrm{D}$ & $\begin{array}{l}\text { Explants' } \\
\text { types }\end{array}$ & $\begin{array}{l}\text { Percentage of } \\
\text { Callus formation }\end{array}$ & $\begin{array}{l}\text { Callus potential } \\
\text { growth classification }\end{array}$ & $\begin{array}{l}\text { callus hardiness } \\
\text { classification }\end{array}$ & $\begin{array}{l}\text { Shoots } \\
\text { per callus }\end{array}$ \\
\hline $\mathrm{T} 1$ & 0 & leaves & $100 \pm 0.00$ & $0.80 \pm 0.18$ & $5.00 \pm 0.00$ & $0.90 \pm 0.00$ \\
\hline $\mathrm{T} 2$ & 0 & peridol & $73.3 \pm 2.40$ & $1.20 \pm 0.00$ & $5.00 \pm 0.00$ & $1.19 \pm 0.01$ \\
\hline $\mathrm{T} 3$ & 0 & Upper stem & $100 \pm 0.00$ & $1.00 \pm 0.14$ & $5.00 \pm 0.00$ & $1.62 \pm 0.02$ \\
\hline $\mathrm{T} 4$ & 0 & Lower stem & $86.7 \pm 2.40$ & $1.80 \pm 0.13$ & $5.00 \pm 0.00$ & $1.19 \pm 0.01$ \\
\hline $\mathrm{T} 5$ & 0.5 & leaves & $100 \pm 0.00$ & $1.80 \pm 0.16$ & $3.50 \pm 0.11$ & $1.70 \pm 0.12$ \\
\hline T6 & 0.5 & peridol & $83.3 \pm 1.40$ & $2.00 \pm 0.14$ & $4.30 \pm 0.15$ & $1.10 \pm 0.11$ \\
\hline $\mathrm{T} 7$ & 0.5 & Upper stem & $76.7 \pm 2.40$ & $1.80 \pm 0.28$ & $3.20 \pm 0.10$ & $1.30 \pm 0.01$ \\
\hline $\mathrm{T} 8$ & 0.5 & Lower stem & $100 \pm 0.00$ & $3.60 \pm 0.22$ & $1.50 \pm 0.08$ & $1.10 \pm 0.16$ \\
\hline T9 & 1 & leaves & $100 \pm 0.00$ & $2.20 \pm 0.15$ & $4.00 \pm 0.10$ & $0.80 \pm 0.11$ \\
\hline $\mathrm{T} 10$ & 1 & peridol & $76.7 \pm 2.40$ & $1.20 \pm 0.31$ & $3.90 \pm 0.12$ & $0.56 \pm 0.06$ \\
\hline $\mathrm{T} 11$ & 1 & Upper stem & $70.0 \pm 3.30$ & $2.60 \pm 0.11$ & $2.10 \pm 0.10$ & $0.26 \pm 0.01$ \\
\hline $\mathrm{T} 12$ & 1 & Lower stem & $96.7 \pm 2.40$ & $3.80 \pm 0.15$ & $1.00 \pm 0.00$ & $0.79 \pm 0.01$ \\
\hline $\mathrm{T} 13$ & 1.5 & leaves & $100 \pm 0.00$ & $1.60 \pm 0.21$ & $4.00 \pm 0.14$ & $0.32 \pm 0.08$ \\
\hline $\mathrm{T} 14$ & 1.5 & peridol & $93.3 \pm 2.53$ & $2.40 \pm 0.14$ & $4.10 \pm 0.23$ & $0.60 \pm 0.01$ \\
\hline T15 & 1.5 & Upper stem & $63.3 \pm 2.33$ & $1.80 \pm 0.14$ & $3.10 \pm 0.11$ & $0.12 \pm 0.01$ \\
\hline T16 & 1.5 & Lower stem & $90 \pm 1.33$ & $2.80 \pm 0.13$ & $1.50 \pm 0.11$ & $0.60 \pm 0.01$ \\
\hline $\mathrm{T} 17$ & 2 & leaves & $96.7 \pm 2.40$ & $2.20 \pm 0.23$ & $3.50 \pm 0.15$ & $0.42 \pm 0.02$ \\
\hline $\mathrm{T} 18$ & 2 & peridol & $100 \pm 0.00$ & $2.60 \pm 0.14$ & $2.90 \pm 0.07$ & $0.16 \pm 0.02$ \\
\hline T19 & 2 & Upper stem & $83.3 \pm 2.33$ & $2.80 \pm 0.18$ & $2.90 \pm 0.21$ & $0.00 \pm 0.00$ \\
\hline $\mathrm{T} 20$ & 2 & Lower stem & $93.3 \pm 2.53$ & $2.20 \pm 0.28$ & $2.00 \pm 0.24$ & $0.54 \pm 0.04$ \\
\hline $\mathrm{T} 21$ & 2.5 & leaves & $100 \pm 0.00$ & $2.80 \pm 0.18$ & $3.50 \pm 0.11$ & $0.30 \pm 0.01$ \\
\hline $\mathrm{T} 22$ & 2.5 & peridol & $80 \pm 2.73$ & $2.20 \pm 0.14$ & $2.20 \pm 0.18$ & $0.30 \pm 0.02$ \\
\hline $\mathrm{T} 23$ & 2.5 & Upper stem & $73.3 \pm 4.40$ & $2.20 \pm 0.13$ & $1.80 \pm 0.22$ & $0.30 \pm 0.01$ \\
\hline $\mathrm{T} 24$ & 2.5 & Lower stem & $96.7 \pm 2.40$ & $3.20 \pm 0.14$ & $1.00 \pm 0.14$ & $0.86 \pm 0.01$ \\
\hline $\mathrm{T} 25$ & 3 & leaves & $100 \pm 0.07$ & $2.00 \pm 0.07$ & $3.50 \pm 0.07$ & $0.80 \pm 0.07$ \\
\hline $\mathrm{T} 26$ & 3 & peridol & $60 \pm 0.08$ & $1.60 \pm 0.08$ & $3.20 \pm 0.08$ & $0.10 \pm 0.08$ \\
\hline $\mathrm{T} 27$ & 3 & Upper stem & $100.0 \pm 0.00$ & $1.00 \pm 0.00$ & $3.80 \pm 0.00$ & $0.00 \pm 0.00$ \\
\hline $\mathrm{T} 28$ & 3 & Lower stem & $90 \pm 0.02$ & $2.20 \pm 0.02$ & $2.00 \pm 0.02$ & $0.28 \pm 0.02$ \\
\hline
\end{tabular}

Table 2. Effect of inoculum size on cell growth in Dendranthema indicum var. aromaticum suspension cultures

\begin{tabular}{|c|c|c|c|}
\hline $\begin{array}{l}\text { Inoculum } \\
\text { mass }(\mathrm{g})\end{array}$ & $\begin{array}{l}\text { Cell fresh } \\
\text { weight }(\mathrm{g})\end{array}$ & $\begin{array}{l}\text { proliferation } \\
\text { ratio }\end{array}$ & Cell Growth status \\
\hline 1 & $1.71 \pm 0.48$ & $71.0 \mathrm{~B}$ & $\begin{array}{l}\text { Good dispersion, cell cluster small and } \\
\text { pale yellow, medium clear }\end{array}$ \\
\hline 2 & $3.77 \pm 0.53$ & $88.5 \mathrm{~A}$ & $\begin{array}{l}\text { Excellent dispersion, cell cluster small and } \\
\text { pale yellow, clear }\end{array}$ \\
\hline 3 & $4.59 \pm 0.78$ & $53.0 \mathrm{C}$ & $\begin{array}{l}\text { Bad dispersion, cell cluster big and dark } \\
\text { yellow, a little turbidity }\end{array}$ \\
\hline 4 & $5.88 \pm 0.49$ & $47.0 \mathrm{D}$ & Bad dispersion, cell cluster big and dark yellow, turbidity \\
\hline
\end{tabular}

The suspension cultures were cultivated in MS medium containing $0.5 \mathrm{mg} \cdot 1^{-1} 2,4-\mathrm{D}$ and $0.2 \mathrm{mg} \cdot 1^{-1} \mathrm{BA}$ on a rotary shaker. Data are expressed as means e S.D. $(n=3)$.

Note: $A \sim D$ is the variance analysis of LSD letter notation, $\mathrm{a}=0.01$, All values are $\mathrm{T}$ statistical data after $18 \mathrm{~d}$ culture. 
Table 3. Effects of exogenous plant growth regulators on cell suspension cultures in Dendranthema indicum var. aromaticum

\begin{tabular}{lllll}
\hline \multirow{2}{*}{$\begin{array}{l}\text { Treatment } \\
\text { Code }\end{array}$} & \multicolumn{3}{l}{$\begin{array}{l}\text { exogenous plant growth } \\
\text { regulators (mg. }\end{array}$} & l-1) \\
\cline { 2 - 4 } & 2,4-D & NAA & $6-B A$ & \\
\hline 1 & 0.0 & 0.0 & 0.0 & $1.30 \pm 0.52 \mathrm{bc}$ \\
2 & 0.0 & 0.2 & 0.2 & $1.33 \pm 0.32 \mathrm{bc}$ \\
3 & 0.0 & 0.5 & 0.5 & $0.90 \pm 0.27 \mathrm{c}$ \\
4 & 0.5 & 0.0 & 0.2 & $2.19 \pm 0.35 \mathrm{a}$ \\
5 & 0.5 & 0.2 & 0.5 & $1.54 \pm 0.33 \mathrm{~b}$ \\
6 & 0.5 & 0.5 & 0.0 & $1.62 \pm 0.40 \mathrm{~b}$ \\
7 & 1.0 & 0.0 & 0.5 & $2.06 \pm 0.41 \mathrm{a}$ \\
8 & 1.0 & 0.2 & 0.0 & $0.99 \pm 0.41 \mathrm{c}$ \\
9 & 1.0 & 0.5 & 0.2 & $1.12 \pm 0.33 \mathrm{c}$ \\
\hline
\end{tabular}

The suspension cultures were cultivated on a rotary shaker and collected on day 18 of cultivation. Data indicate means of three independent experiments (means e S.D.)

Note: $\mathrm{a} \sim \mathrm{c}$ is the variance analysis of LSD letter notation, $\mathrm{a}=0.05$, All values are $\mathrm{T}$ statistical data after $18 \mathrm{~d}$ culture.

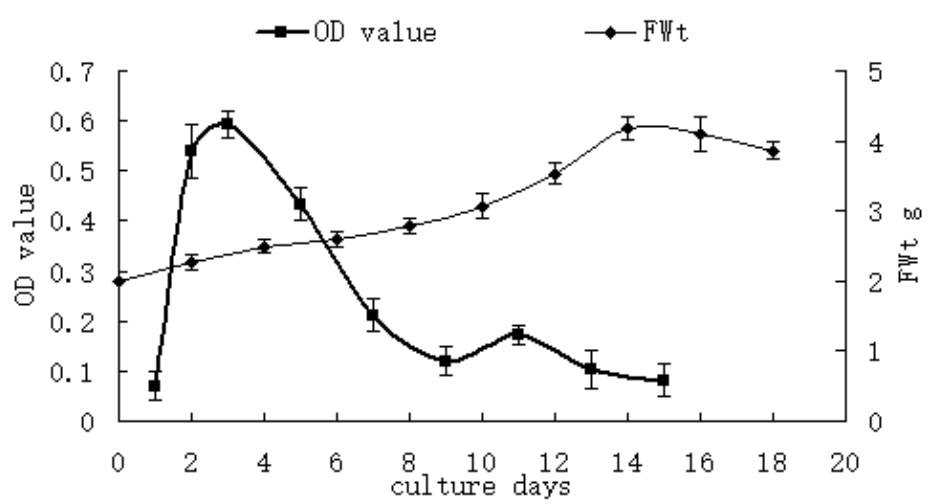

Figure 1. Time course of cell growth and viability in D. indicum var. aromaticum suspension culture

The suspension cells were grown in liquid MS medium containing $0.5 \mathrm{mg} \cdot \mathrm{1}^{-1} 2,4-\mathrm{D}$ and $0.2 \mathrm{mg} \cdot \mathrm{1}^{-1} \mathrm{BA}$ and incubated on a rotary shaker at $(25 \pm 2)^{\circ} \mathrm{C}$ under a 16-h photoperiod and illumination of 1000 lx. Data indicate means of three independent experiments (means e S.D.).

Abbreviations: MS, Murashige and Skoog medium; 6-BA, 6-Benzylaminopurine;2,4D,2,4-Diclorophenoxyacetic acid; 2,3,5-triphenyltetrazolium chloride. I am deeply grateful to Dr. Shunsuke Naruto for his invaluable guidance and advice.

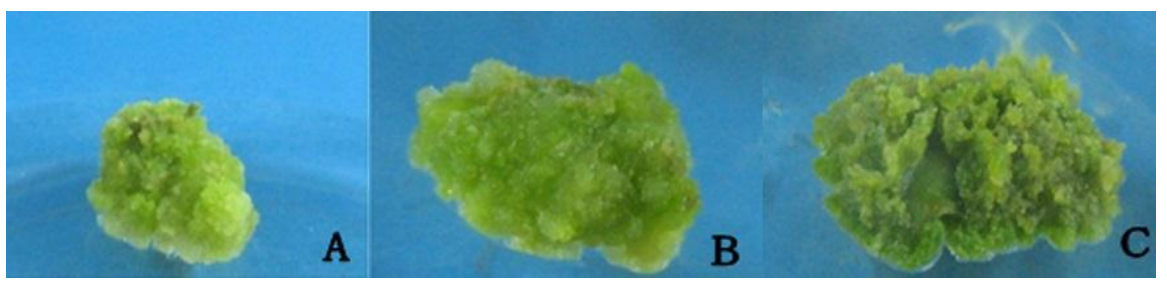

Figure 2. Different types of explants of D. indicum var. aromaticum on the callus induction

A.The callus induction of stem segments.B.The callus induction of leaves .C.The callus induction of petioles. 


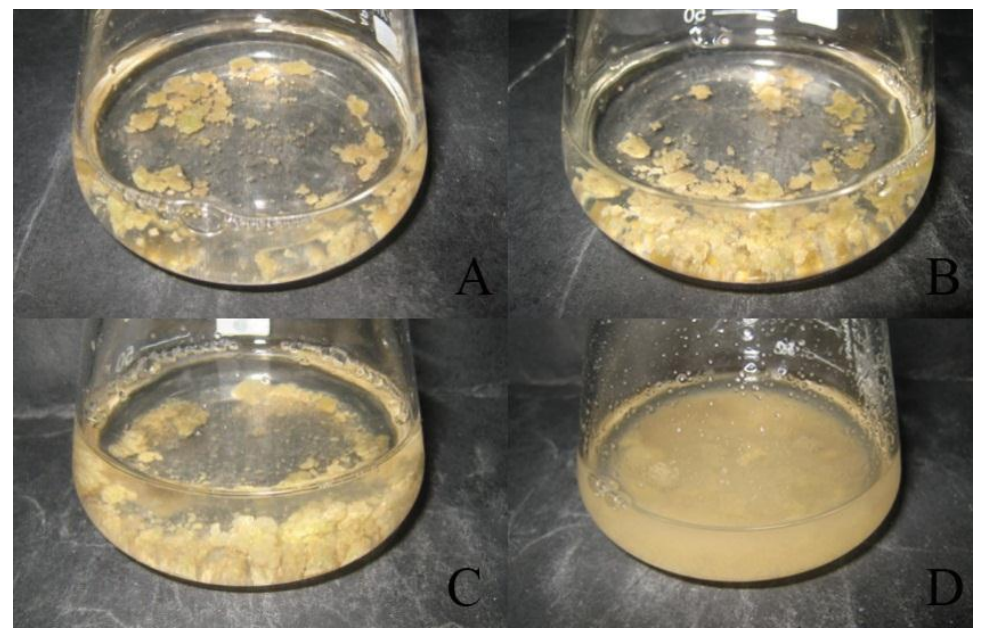

Figure 3. Cells suspension culture growth in different initial quantity of Dendranthema indicum var. aromaticum A. The initial quantity is $1 \mathrm{~g}$.B. The initial quantity is $2 \mathrm{~g}$.C. The initial quantity is $3 \mathrm{~g}$.D. The initial quantity is $4 \mathrm{~g}$.

\section{Acknowledgments}

This research was supported by the National Natural Science Foundation of China (31400590). I am deeply grateful to my teacher for her invaluable guidance and advice.

\section{References}

Chen, F. D., Jiang J. F., \& Guo, W. M. (2003). Study on irradiation breeding of suspension cell of Dendranthema morifolium with small inflorescence I . Selection of genotype, explant and callus induction media. Journal of Nanjing Agricultural University, 4, 006.

Retrieved from http://en.cnki.com.cn/Article_en/CJFDTOTAL-NJNY200304006.htm

Cheng, H., Yu, L. J., Hu, Q. Y., Chen, S. C., \& Sun, Y. P. (2006). Establishment of callus and cell suspension cultures of Corydalis saxicola Bunting, a rare medicinal plant. Zeitschrift für Naturforschung C, 61(3-4), 251-256. https://doi.org/10.1515/znc-2006-3-416

Henn, H. J., Wingender, R., \& Schnabl, H. (1998). Regeneration of fertile interspecific hybrids from protoplast fusions between Helianthus annuus L. and wild Helianthus species. Plant cell reports, 18(3), 220-224. https://dx.doi.org/10.1007/s002990050560

Jiang Jiafu. (2002).Studies on the performance of some traits of F1 generation, cell suspension culture and plant regeration of Dendratehma grandiflora.(Master's thesis, Nanjing Agricultural University). Retrieved from http://kns.cnki.net/KCMS/detail/detail.aspx?dbcode $=$ CMFD\&dbname $=$ CMFD9904\&filename $=2002124433$ .nh\&uid=WEEvREcwSIJHSldRa1FhdkJkcGkzcUJoU2ZEWFBSM1RMZHU2bGFheFJ0QT0=\$9A4hF_YA uvQ5obgVAqNKPCYcEjKensW4ggI8Fm4gTkoUKaID8j8gFw!!\&v=MzI1MjZLNkd0WFBySkViUEISOG VYMUx1eFITNORoMVQzcVRyV00xRnJDVVJMMmZaT2RvRnlEblVyL0IWMTI3SEw=

Keskitalo, M., Angers, P., Earle, E., \& Pehu, E. (1999). Chemical and genetic characterization of calli derived from somatic hybridization between tansy (Tanacetum vulgare L.) and pyrethrum (Tanacetum cinerariifolium (Trevir.) Schultz-Bip.). Theoretical and applied genetics, 98(8), 1335-1343. https://dx.doi.org/10.1007/s001220051200

Krasnyanski, S., \& Menczel, L. (1995). Production of fertile somatic hybrid plants of sunflower and Helianthus giganteus L. by protoplast fusion. Plant cell reports, 14(4), 232-235. https://dx.doi.org/ 10.1007/BF0023363

Lee, C. H., Paek, K. Y., \& Hwang, J. K. (1995). Somatic hybridization between Dendranthema grandiflorum and Salpiglossis sinuata via protoplast fusion. Korean Journal of Breeding (Korea Republic), 27(3), 290-297. http://lib.rda.go.kr/newlib/adlib_en/index.html

Li Yong et al., (2007).Research on the growth regularity and physiological characteristics of Mulberry suspension cells. Science of Sericulture, 33(1), 91-94.

Retrieved from http://en.cnki.com.cn/Article_en/CJFDTOTAL-CYKE200701016.htm 
Liu Hua. (2002). The relationship of the growth of Taxus chinensis cell in suspension culture to the viability and subsistence rate. Journal of Biology, 18(1), 19-20.

Retrieved from http://en.cnki.com.cn/Article_en/CJFDTOTAL-SWXZ200201006.htm

Liu Lei. (2009).Establishment of suspension culture and isolation of protoplasts in xanthoceras sorbifolia Bunge. (Master's thesis, Agricultural university of Hebei, Baoding). Retrieved from http://kns.cnki.net/KCMS/detail/detail.aspx?dbcode $=$ CMFD\&dbname $=$ CMFD2009\&filename $=2009132005$ .nh\&v=MTEyMjZLNOhOSE1xcEViUEISOGVYMUx1eFITNORoMVQzcVRyV00xRnJDVVJMMmZaT2 RvRkNua1ViM09WMTI3Rjc $=$

Liu, Q., Jia, W., \& Yang, D. (1983). The investigation on geographical distribution, ecological habit and storage quantity on a new resource plant of Hubei, Dendrathma indicum (L.) Des Monl.Var.aromaticum. Journal of Wuhan Botanical Research, 1(2), 239-246. Retrieved from http://xueshu.baidu.com/s?wd=paperuri\%3A\%287d3a9ac53b232d4ab4bb3503a3101f2a\%29\&filter=sc_lon g_sign\&tn=SE_xueshusource_2kduw22v\&sc_vurl=http\%3A\%2F\%2Fen.cnki.com.cn\%2FArticle_en\%2FCJ FDTotal-WZXY198302014.htm\&ie=utf-8\&sc_us=8046499129164148898

Murashige, T., \& Skoog, F. (1962). A revised medium for rapid growth and bio assays with tobacco tissue cultures. Physiologia plantarum, 15(3), 473-497. https://dx.doi.org/10.1111/j.1399-3054.1962.tb08052

Satyavani, K., Ramanathan, T., \& Gurudeeban, S. (2011). Effect of plant growth regulators on callus induction and plantlet regeneration of bitter apple (Citrullus colocynthis) from stem explant. Asian Journal of Biotechnology, 3, 246-253. https://doi.org/10.3923/ajbkr.2011.246.253

Steponkus, P. L., \& Lanphear, F. O. (1967). Refinement of the triphenyl tetrazolium chloride method of determining cold injury. Plant Physiology, 42(10), 1423-1426. https://dx.doi.org/10.1104/pp.42.10.1423

Zhou, Y. B., Wang, R., \& Xiao, D. G. (2007). Establishment of Cleistocalyx-operculatus' Suspension Cell Lines and Study on Its Vegetative Character on Suspension Culture. Biotechnology. Retrieved from http://en.cnki.com.cn/Article_en/CJFDTOTAL-SWJS200701023.htm

Zhu, M. L., Liu, Q. Q., \& Dai, S. L. (2011). Karyotype analysis of 38 large-flowered chrysanthemum cultivars from China. Chinese Bulletin of Botany, 46(4), 447-455. https://doi.org/10.3724/SP.J.1259.2011.00447

\section{Copyrights}

Copyright for this article is retained by the author(s), with first publication rights granted to the journal.

This is an open-access article distributed under the terms and conditions of the Creative Commons Attribution license (http://creativecommons.org/licenses/by/4.0/). 